\title{
References, authors, journals and scientific disciplines underlying the sustainable development literature: a citation analysis
}

\author{
Nuno Quental · Júlia M. Lourenço
}

Received: 4 February 2011 / Published online: 16 October 2011

(C) Akadémiai Kiadó, Budapest, Hungary 2011

\begin{abstract}
This paper identifies the main references, authors and journals influencing the sustainable development literature. The task is accomplished by means of a citation analysis based on the records of ISI Web of Science. We found that the core of sustainability thinking is framed by a pattern of landmark studies published around every 5 years. Only 380 publications have been cited at least ten times. References with the highest influence are those with a global dimension and large diffusion, such as Brundtland Commission's "Our common future" (1987) and classics such as Meadows' et al. "Limits to growth" (1972). The list of the most influential references over the period 1960-2005 is dominated by contributions from economics (particularly ecological economics) and environmental science, but includes many other disciplines such as urban planning, political sciences and sociology. References are also made to policy documents such as "Agenda 21", one of the main outcomes of the Rio Summit in 1992. In analyzing citation trends, we found that 'classics', because of their high rates of citations per year, seem to have a more enduring and stable influence.
\end{abstract}

Keywords Sustainable development - Sustainability science - Ecological economics · Bibliometric assessment · Citation analysis

\section{Introduction}

Sustainable development has definitely entered the lexicon of scientists, politicians and even citizens. The World Commission on Environment and Development (WCED) coined back in 1987 the most common definition of sustainable development proposed so far: "the development that meets the needs of the present generation without compromising the ability of future generations to meet their own needs" (WCED 1987). The concept arose

N. Quental $(\bowtie) \cdot$ J. M. Lourenço

Department of Civil Engineering, University of Minho, Campus de Azurém,

4800-058 Guimarães, Portugal

e-mail: quental.nuno@gmail.com 
mainly as a political compromise during the works of the Commission, which probably accounts for its multiple available interpretations.

Previous research by the authors attempted to clarify existing views on sustainable development and how they evolved by means of two literature reviews: one centered at the political milestones (Quental et al. 2011b), and another centered at the scientific dimension (Quental et al. 2011a). It was concluded, from the political point of view, that sustainable development is characterized by seven main goals: (a) sustaining natural capital such as biodiversity, water, and air; (b) sustaining life support systems such as ecosystems, ecosystem services, and natural resources; (c) minimizing human impacts such as climate change, pollution, waste, and population growth; (d) developing human capital such as human rights, political liberties, learning, equity, health, and wealth; (e) developing social capital such as solidarity, community, and culture; (f) developing the economy, including agriculture, the employment market and technology; and (g) developing institutions, e.g. promoting good governance, democracy, transparency, public participation, and international cooperation. From the scientific point of view, Quental et al. (2011a) argued that the concept of sustainable development is connected with numerous scientific approaches such as sustainability science. Sustainability science, as such, can be considered the "scientific arm" of sustainable development. Its research program is intrinsically multidisciplinary and focuses on the "dynamic interactions between nature and society, with equal attention to how social change shapes the environment and how environmental change shapes society" (Clark and Dickson 2003; Kates et al. 2001). Quental et al. (2011a) also concluded that approaches related to sustainable development are (a) becoming more integrative and dynamic by tying together the characteristics of the ecosystems and those of society, namely through the introduction of concepts such as resilience and vulnerability; (b) shifting their concern from human impacts and availability of natural resources to a more balanced position that puts human and social capital at the center; and (c) embedding research in the wider values of society, namely by defining research priorities according to the rules of saliency, credibility, and legitimacy.

This paper represents further research from the authors aiming to clarify the sources and influences underlying the concept of sustainable development. Instead of performing a literature review, however, this research resorts to a citation analysis based on the rich source of reference information available from ISI Web of Science. It complements previous research (Quental et al. 2011a, b) by providing a more objective assessment capable not only of confirming and exploring from a quantitative point of view some of our findings, but also of proposing new undetected influences underlying the concept of sustainable development.

As a first step, it is important to clearly define the scope of the present bibliometric assessment. Other assessments on related topics (Costanza et al. 2004; Kajikawa et al. 2007; Ma and Stern 2006) seem to have been too inclusive, creating difficulties in defining the object of the study. Schubert and Lang (2005), on the contrary, concentrated on the references citing the Brundtland report. Our main target is wider than the latter but still rather focused: the body of literature directly addressing sustainable development. This includes extensive primary and secondary literature discussing the concept directly (e.g., papers from the field of ecological economics and literature reviews), as well as primary literature whose core topic is not sustainable development but which analyzes the implications of research findings it terms of sustainability. All these papers are of interest to the present study because they allow a rather complete picture of the main sources influencing researchers explicitly referring to sustainable development. 
The following section discusses the use of bibliometric assessments and reviews previous citation analysis of interest to this paper. Third section details the methodology used and fourth section presents the results achieved. The last section deals with the conclusions.

\section{The use of bibliometric assessments}

Metrics of scientific activity and influence have been used at least since 1972 when Garfield (1972) proposed the nowadays widely used journal Impact Factor. Since then, scholars have embraced long discussions about the usefulness of such metrics, particularly because funding agencies are also using them to decide on how to invest their resources. Invariably, metrics are based on citations.

Although metrics of scientific activity should be as objective as possible, numerous factors affect citing behavior. MacRoberts and MacRoberts (1996) identified the following: not citing influences (either on purpose or because it is common practice in certain fields), biased citing, preference for secondary sources, avoidance of informal influences, citing culture of a scientific field, excessive self-citation, size of the audience, and technical problems related to how data is entered or stored. Bornmann and Daniel (2008) added factors such as time (recent papers are more likely to be cited because the scientific production is increasing), journal's characteristics (as both higher Impact Factors and number of issues published per year tend to increase citation rates), article type (state of the art review papers tend to obtain larger citation counts compared to other types of papers), gender of the author (with males receiving more citations) and paper availability. In addition to these influencing factors, Vieira and Gomes (2010) found that papers tend to be more often cited when their number of references, number of pages, and number of coauthors also increase (factors sorted by order of importance). Their results were obtained based on the characteristics of more than 220 thousand papers published in the fields of biology, chemistry, mathematics and physics.

Despite MacRoberts and MacRoberts (1996) claim that "the basic assumptions of citation analysis are clearly false", it is noteworthy that metrics of scientific activity seem to remain one of the most important information sources to assess the influence or credibility of research institutions, researchers, or papers. As such, this paper follows Bornmann and Daniel's (2008) line of reasoning when they argue that "at a high aggregation level [bibliometric studies] demonstrated a clear association between citation counts and other assessments of scientific impact, such as peer judgments", or that "there is evidence that the different motivations of citer are not so different or randomly given to such an extent that the phenomenon of citation would lose its role as a reliable measure of impact". As a consequence, this study assumes that "the research cited by scientists in their own papers represents a roughly valid indicator of influence on their work" (Cole and Cole 1972, as cited in MacRoberts and MacRoberts 1996).

While acknowledging the limitations of bibliometric assessments, the characteristics of our analysis make it less vulnerable to some of the criticisms of science metrics. Firstly, it is substantially different than computing a journal's Impact Factor or estimating the success of a researcher's career, which lead to highly competitive comparisons between the affected parties. This paper does not face that problem essentially because it aims to identify the main theoretical influences of the sustainable development literature, and not to achieve a very precise method of ranking them. Secondly, this paper focuses on a defined scientific field, escaping the potential danger of mixing fields with different citation 
cultures (e.g., Glänzel and Moed 2002). Our study therefore explores the opportunity of connecting research on sustainable development with the evolving area of scientometrics, hopefully leading to fruitful insights and conclusions.

There are only a few other bibliometric assessments on topics related to sustainable development. One example is the study by Kajikawa et al. (2007), who identified the topics covered by scientific literature containing "sustainab*" in their titles, abstracts, or keywords. This search term was used to target the sustainability science literature, but such criterion was too inclusive (the search term covers for example both "sustainability" and "sustainable"), probably leading to the incorporation of a large number of papers only marginally related to sustainability science. Not surprisingly, they found 15 main research clusters, with a predominance of agriculture, fisheries, ecological economics, and forestry.

Two other studies aimed at identifying the most influential publications in the fields of environmental economics and/or ecological economics. The first was performed by Costanza et al. (2004), who concentrated on the journal Ecological Economics between 1994 and 2003. Their research included book citations in addition to paper citations and they added complementary methods such as the nomination of the most influential publications by the Ecological Economics' editorial board. The second study, by Ma and Stern (2006), identified the papers most often cited in the Journal of Environmental Economics and Management and in Ecological Economics between 1994 and 2003. One might argue, however, that defining a scientific field by the papers published in two main journals is a restrictive assumption because it discards all papers related to the object of study published in other journals.

This paper attempts to avoid the methodological shortcomings identified above by confining the analysis to those papers that are very likely related to sustainable development. Contrarily to Costanza et al. (2004) and to Ma and Stern (2006), this assessment spans through all the journals indexed by ISI Web of Science and covers all reference types (books, papers, etc.), thus not excluding a priori contributions from any scientific discipline. We are convinced that the scope of this citation analysis provides a very clear picture of the influences underlying the sustainable development literature.

\section{Methodology}

The bibliometric assessment was carried out over the extensive database of ISI Web of Science (ISI 2008), which contains over 40 million records from more than 10,000 journals. Scientific disciplines are distributed through three datasets: the Science Citation Index Expanded (1900-), the Social Sciences Citation Index (1956-) and the Arts and Humanities Citation Index (1975-). These three datasets were searched simultaneously through the web interface of the Web of Science in October 2008.

Gathering of the source literature

As a first step, all the records that contained the expressions "sustainable development" or "sustainability science" in their title, abstract or keywords were retrieved. Both expressions were used because, according to the authors' experience (Quental et al. 2011a, b), they are commonly used in the literature we wanted to target. Moreover, these expressions were preferred rather than "sustainable" or "sustainability" to avoid including papers that had little to do with the subject, since those words are extremely common and can be used in a variety of contexts. The option was therefore to use narrow and precise criteria to 
maximize the probability that the retrieved papers really addressed sustainable development issues. The search yielded 7,800 records-the first record dating from 1981. The list was further restricted to those papers with two or more citations in order to increase the scientific relevance of the selected literature. After applying this criterion, the number of papers was reduced to 3,334 .

Analysis of scientific production and of its disciplinary evolution

The list of 3,334 records was used directly as a source to analyze both the evolution of scientific production and the disciplines covered. Scientific production was computed simply by counting the number of papers published per year. Regarding scientific disciplines, the classification supplied by ISI for each paper was used as source. This classification was then simplified according to the second tier groups found in Wikipedia (2011).

Initial compilation of the cited references database

The references contained in each of the 3,334 papers were also studied in order to find out the most influential publications, primary authors, and journals. First, all the cited references were joined into a single Excel file. This yielded as much as 127,000 records (an average of 38 references per paper). Variants of the same publication were aggregated because books and other publications (which are not indexed by the Web of Science) are registered in the database as they were typed by the authors of the citing paper (and usually in an abbreviated form). For instance, Brundtland's report author could be typed e.g. as "WCED," "BRUND COMM," "BRUNDTLAND G," "United Nations WORLD COMM ENV". The aggregation required the combination of information from author, title and date in order to avoid mistakes. Papers indexed by ISI did not suffer from these problems, since their information was precisely registered. From this step onwards, database consolidation varied according to the purpose of the analysis.

Identification of the most influential publications

The aggregation procedure was further developed by shortening titles and author names to their first word (titles retained two words if the first was less than 5 characters long). While maintaining the integrity of the database (ensured through the combination of author, title and date) this method allowed for a practical cleaning of name and title variants (for instance, "DALY HE" and "DALY H" were changed into "DALY"). In addition, care was taken to group all editions of a same book, since they could be typed with different dates. The next step of the procedure was the consolidation of the database in order to obtain unique records and count the number of occurrences of each. A total of 97,600 different publications were obtained, of which the vast majority (87\%) was cited only once. However, the use of citation counts alone could be misleading since it would favor older publications. To avoid this pitfall, citation counts were divided by the number of papers published after the reference in question. To illustrate this point, Kates et al. (2001) was cited 56 times; because only 1,623 papers (from the set of 3,334 records) have been published since 2002, the result obtained was 3.5\%-ranking higher (6th place) than what would be expected solely from the citation counts (14th place). At the same time, though, this method could lead to inconsistent results on recent publications even with a small 
number of citations. Therefore, only references with 10 or more citations were considered in this analysis.

Identification of the most influential primary authors

The identification of the most influential primary authors required a slightly different procedure. Author names were shortened to their first word followed by the first letter of the second word. For instance, "DALY HE" and "DALY H" were both changed into "DALY H". This was especially important for common surnames, such as "SMITH", which could misleadingly rank high if only the first word was retained.

\section{Results}

This section presents the results from the bibliometric assessment, namely the identification of the most influential publications, authors, and journals. It also highlights the scientific disciplines and principles underlying the concept of sustainable development.

As a general remark, it is important to distinguish between the source literature and the references cited by the source literature. The source literature refers to the papers tracked by ISI Web of Knowledge that contain "sustainable development" or "sustainability science" in their title, abstract or keyword, and that were cited in their database at least two times. On the contrary, the references cited by the source literature refer, as the name indicates, to the group of all citations found on the source literature. To make the distinction clear, this section is divided accordingly.

\section{Source literature}

\section{Descriptive statistics}

Table 1 presents general descriptive statistics about the source literature, which comprises a total of 3,334 papers published between 1981 and 2008. On average, each paper has been cited 9.6 times as tracked by ISI Web of Knowledge. Taken together, these conditions provide a solid basis for the bibliometric assessment.

Almost three quarters of the papers were classified by ISI as articles, around $16 \%$ as papers published in proceedings, and $8 \%$ as reviews (Table 2). Other paper types were of minor significance.

Table 1 Descriptive statistics for the source literature used in the bibliometric analysis

Inclusion criterion: title, abstract or keyword containing "sustainable development" or "sustainability science; times cited in ISI Web of

Knowledge $\geq 2$

\begin{tabular}{ll}
\hline Statistic & Description \\
\hline $\begin{array}{l}\text { Number of papers } \\
\text { Range of publication dates }\end{array}$ & 3,334 \\
Average publication date & $1981-2008$ \\
Range of times cited in ISI Web & 2000 \\
$\quad \begin{array}{l}\text { of Knowledge per paper } \\
\text { Average of times cited in ISI Web } \\
\text { of Knowledge per paper }\end{array}$ & $2-239$ \\
\hline
\end{tabular}


Table 2 Source literature sorted by type of paper

\begin{tabular}{lc}
\hline Type of paper & Percentage of the total \\
\hline Article & 72.6 \\
Proceedings paper & 15.7 \\
Review & 7.7 \\
Editorial material & 3.4 \\
Note & 0.1 \\
Book review & 0.1 \\
Discussion & 0.1 \\
Reprint & 0.1 \\
News item & 0.1 \\
Letter & 0.1 \\
\hline
\end{tabular}

Scientific production

The number of scientific papers published per year containing the expressions "sustainable development" or "sustainability science" in their title, abstract or keywords, is displayed in Fig. 1.

The figure suggests the existence of a "starting" period until the end of the eighties and a "mature" period characterized by a large and escalating number of published papers. There are however, two periods that can be characterized as stagnant: around 1996-1999 and around 2001. Indicators of political activity related to sustainable development also suggested the existence of such stagnation periods (Quental et al. 2011b). Although it's difficult to point out specific causes for such cycles, Quental et al. (2011b) proposed that decennial Earth Summits act as catalysts of political action, possibly also influencing

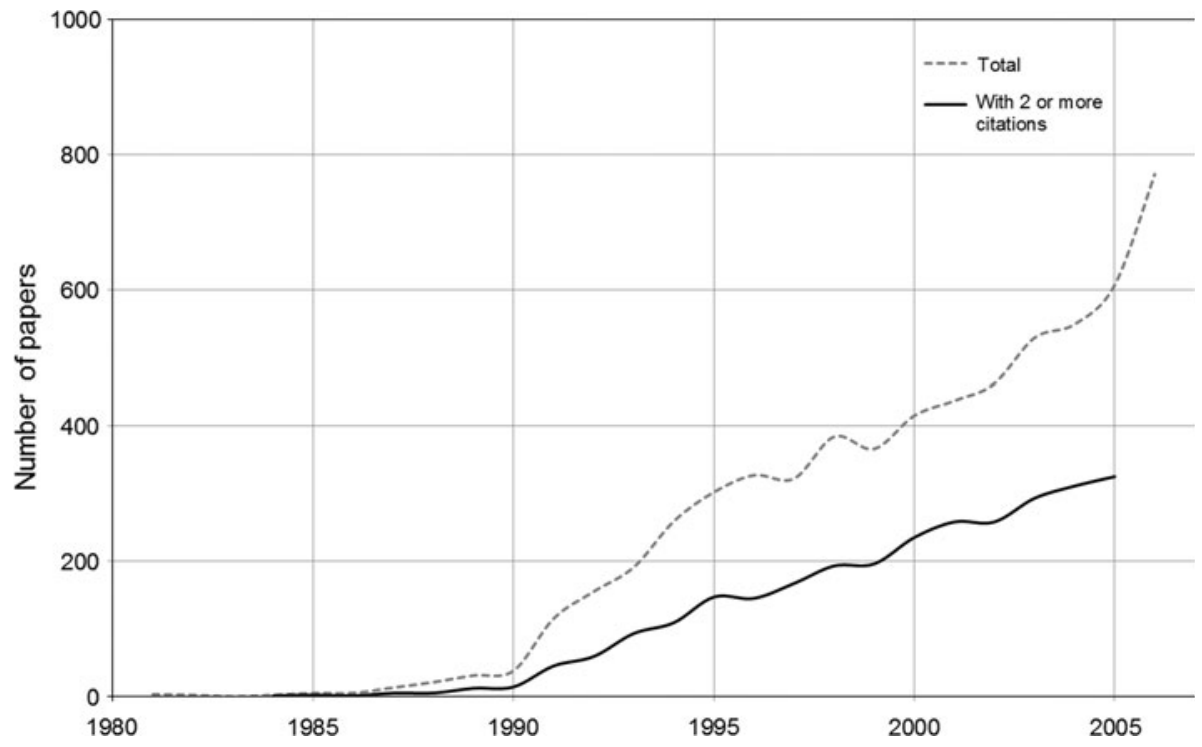

Fig. 1 Number of articles published per year containing "sustainable development" or "sustainability science" in their title, abstract or keywords in ISI (2008) 
scientific production. It is noteworthy, for example, that the number of papers started to escalate shortly after the Rio Summit in 1992.

Scientific disciplines

Table 3 presents the entire collection of sustainable development papers with two or more citations grouped by scientific discipline. Figure 2 complements this information with the publication trends among the five most important disciplines.

The striking conclusion is that the vast majority (70\%) of sustainable development papers are from the environmental sciences and $22 \%$ from biological sciences, with an upward tendency. This gives credit to the common assumption that environmental issues are in fact at the core of sustainable development, even if in theory at least social and economic issues should be acknowledged in a balanced way (Quental et al. 2011b). It is also interesting to note that papers dealing with urban issues represent around $13 \%$ of the sustainable development literature, but their share is diminishing. Such results seem to contradict the idea that urban sustainability is one of the major sustainable development

Table 3 Source literature papers classified according to ISI scientific disciplines
${ }^{\text {a }}$ ISI classifies each paper into usually more than one discipline, so the total does not add up to 3,334 nor to $100 \%$

\begin{tabular}{|c|c|c|}
\hline Discipline & $\begin{array}{l}\text { Number of } \\
\text { papers }^{\mathrm{a}}\end{array}$ & $\begin{array}{l}\text { Percentage } \\
\text { of total }^{\mathrm{a}}\end{array}$ \\
\hline Environmental science & 2,318 & 70 \\
\hline Biology & 722 & 22 \\
\hline Urban studies, planning and transportation & 415 & 12 \\
\hline Economics & 371 & 11 \\
\hline Geography & 370 & 11 \\
\hline Physics & 349 & 10 \\
\hline Engineering & 320 & 10 \\
\hline Sociology & 200 & 6.0 \\
\hline Agronomy & 182 & 5.5 \\
\hline Chemistry & 172 & 5.2 \\
\hline Political science & 168 & 5.0 \\
\hline Earth science & 155 & 4.6 \\
\hline Management & 124 & 3.7 \\
\hline Health science & 114 & 3.4 \\
\hline Multidisciplinary & 92 & 2.8 \\
\hline Computer science & 56 & 1.7 \\
\hline Philosophy & 44 & 1.3 \\
\hline Education & 32 & 1.0 \\
\hline Anthropology & 26 & 0.8 \\
\hline Spatial science & 22 & 0.7 \\
\hline Mathematics & 20 & 0.6 \\
\hline Psychology & 15 & 0.4 \\
\hline Cognitive science & 11 & 0.3 \\
\hline Statistics & 5 & 0.1 \\
\hline Arts & 1 & 0.0 \\
\hline Astronomy & 1 & 0.0 \\
\hline
\end{tabular}






Fig. 2 Evolution of relative contribution of different scientific fields in the sustainable development literature. Source: own work based on ISI (2008)

issues currently at stake (e.g., United Nations Center for Human Settlements 2008; United Nations Population Fund 2007).

\section{References cited by the source literature}

Descriptive statistics

When ISI Web of Knowledge was queried, in October 2008, references with 10 or more citations amounted to 380 and represented only $0.42 \%$ of all (Table 4$)$. The overwhelming majority $(87 \%)$ of references had been cited only once.

Influential publications and citation trends

For the purposes of this section, a smaller list comprising the 60 most influential publications was retained as the basis of our analysis (Appendix Table 7; Fig. 3). As explained in chapter 3 , references were ranked by dividing their citation numbers by the total number of papers published thereafter.

Brundtland Commission's "Our common future" ${ }^{1}$ clearly stands out as the most influential publication. It was cited by $22.5 \%$ of the source literature published thereafter. From our experience, most references made to the Brundtland report refer to the definition about sustainable development it contains, thus suggesting that Brundtland's definition is indeed the most cited.

1 Please note that publications identified as influential are usually absent from the reference list of this paper but can be found in the Appendix (Table 7). 
Table 4 Descriptive statistics for the list of references cited by the source literature

\begin{tabular}{ll}
\hline Statistic & Description \\
\hline Number of citations & 126,958 \\
Number of different references & 97,618 \\
Range of reference dates & $1556-2008$ \\
Average reference date & 1993 \\
Range of citations per reference & $1-744$ \\
Number of references cited once & $84,666(87 \%)$ \\
Number of references cited 2 to 9 times & $12,569(13 \%)$ \\
Number of references cited 10 or more times & $380(0.4 \%)$ \\
Number of references cited 15 or more tomes & $161(0.2 \%)$ \\
Average references per source literature paper & 38 \\
Number of authors with 10 or more citations & 1,822 \\
Number of authors with 50 or more citations & 144 \\
Number of journals with 10 or more citations & 973 \\
Number of journals with 50 or more citations & 173 \\
\hline
\end{tabular}

Another two highly cited reports could also become of pivotal importance if the high rate of citations per year is maintained: the 2001 Intergovernmental Panel on Climate Change's (IPCC) "Third assessment report" (cited by $9.7 \%$ of the papers published after 2001), and the 2005 "Millennium Ecosystem Assessment" (with 5.9\%). As new IPCC reports are released, however, it is expected that previous (somehow outdated) releases receive a decreasing number of new citations (see also "Influential authors and journals" on citation patterns).

About half of the identified publications were also considered as influential in the field of ecological economics or environmental economics by Ma and Stern (2006) and by Costanza et al. (2004). Costanza et al. (2004, pp. 284-290) reached a list of 57 papers and 77 monographs (134 in total) cited at least 15 times in Ecological Economics, which is just below the 161 publications identified by the present research if the same criterion of 15 citations was applied (cf. Table 4).

Interesting insights can also be sought from the analysis of citation trends. Six citation patterns were chosen as exemplary in Fig. 4. References published more than 40 years ago, such as Meadows' et al. "Limits to growth" or Hardin's "The tragedy of the commons", continue to receive a reasonable citations rate (10-20 per year). The example of WCED's "Our Common Future" is exceptional as it is cited more than 100 times every year-even if its influence, measured as the percentage of papers from the sustainable development literature citing it, is slowly decreasing. These results should be analyzed in conjunction with those obtained by Schubert and Lang (2005), who found that citations to the Brundtland report peaked in 1996 and decreased markedly until 2000. They included all citations by scholarly articles as recorded by ISI Web of Knowledge, so direct comparisons with the results obtained here are difficult. There is some consistency regarding the loss of influence over time, although our data suggests that such decrease is not so steep as the one proposed by Schubert and Lang (2005).

The influence of other papers is more complex to analyze. A good example is Redclift's "Sustainable development: exploring the contradiction", which was cited by almost one quarter of all papers on sustainable development published in 1988-1989 and received as much as 18 citations in 1992-1993. As citations per year have decreased to levels of 4 to 


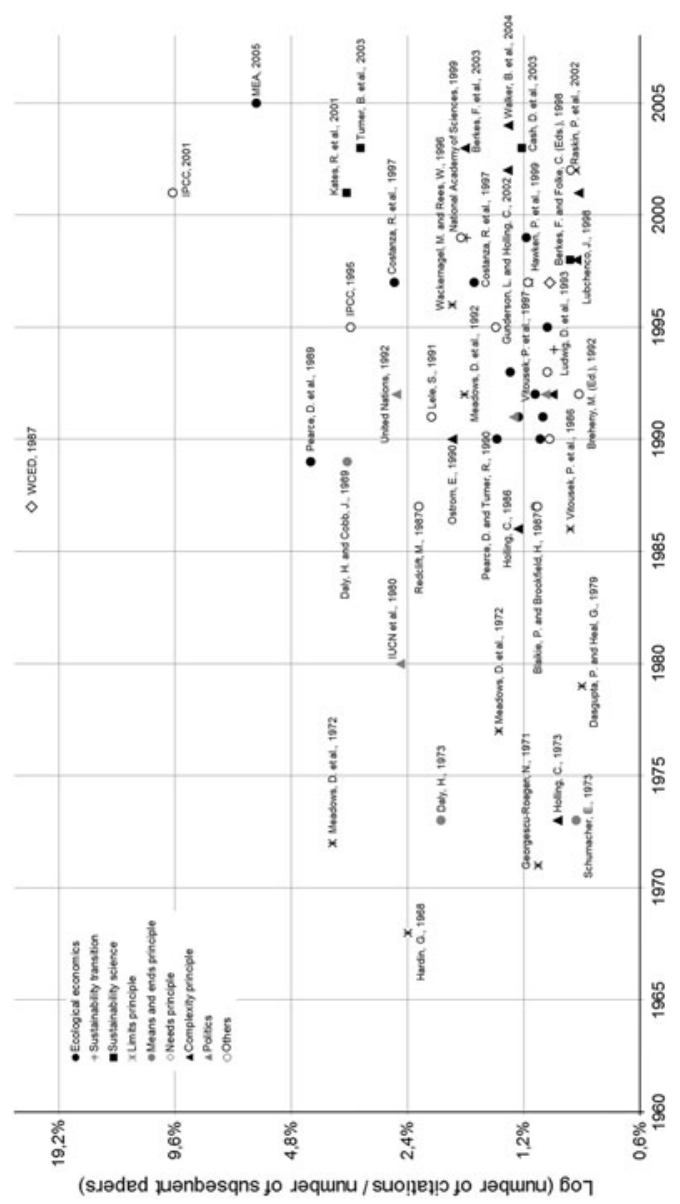

Fig. 3 The 60 most influential publications cited by the source literature. Source: own work based on ISI (2008)

10 and the source literature increased considerably, the influence of the paper diminished steeply but kept a reasonable level. More recent publications presenting novel approaches (Wackernagel and Rees, 1996, and Ostrom, 1990, are shown as examples) are probably facing the first stage of their influence, which is characterized by reasonable citation rates of around 10-16 per year. It remains to be seen if their influence is maintained, as happened with Redclift's paper, or not.

Influential authors and journals

The most cited primary individual authors are from the United States (e.g., Robert Costanza, Herman Daly, C. S. Holling, Robert Ayres, Donella Meadows) and from the United Kingdom (e.g., David Pearce, Michael Redclift, Timothy O'Riordan)—see Table 5. Curiously, none of these authors was identified by Schubert and Lang (2005) as having more than ten papers citing the Brundtland report. 

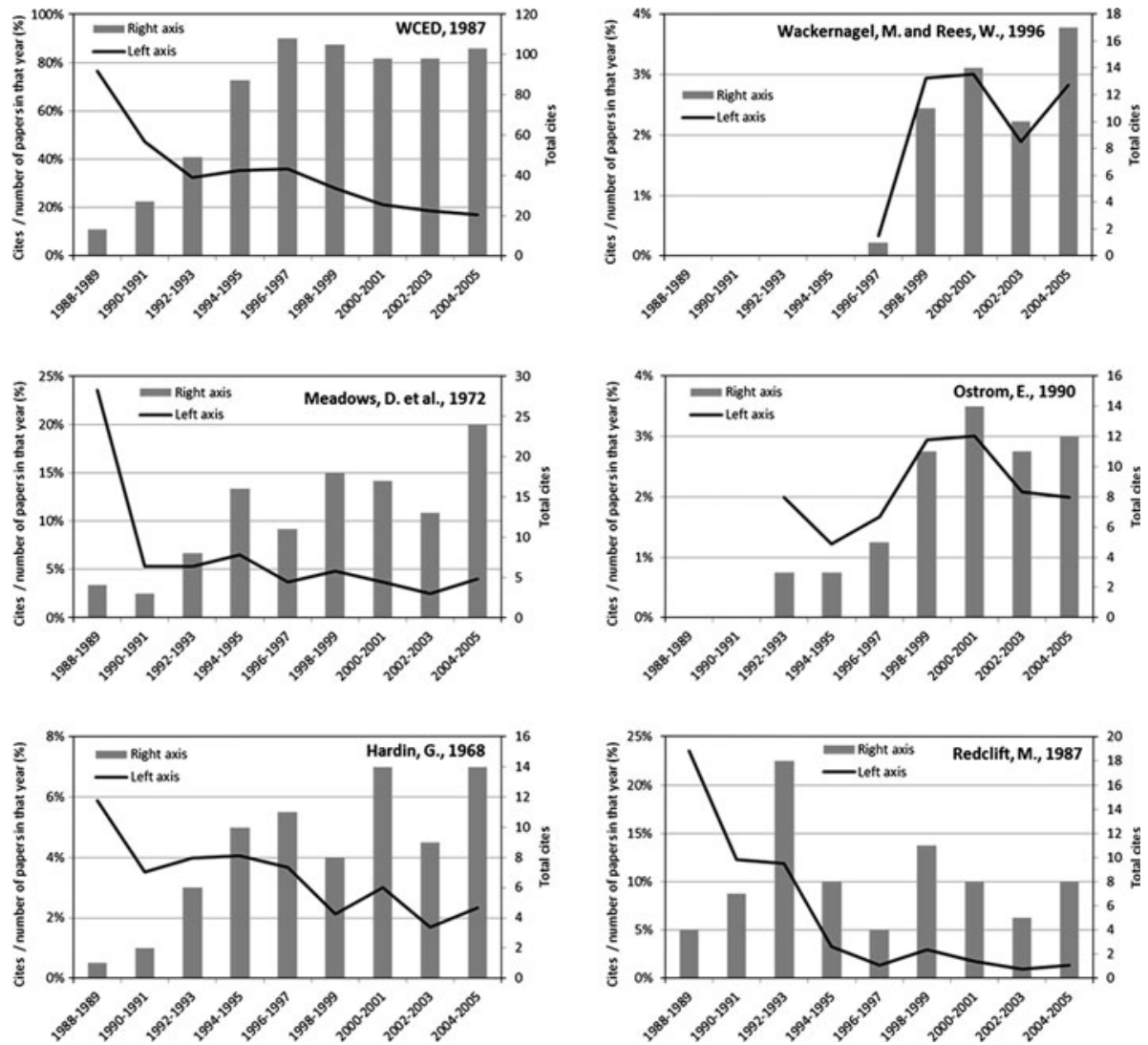

Fig. 4 Patterns of citation trends. Older publications are shown on the left column and more recent publications on the right column. Please mind scale changes across graphics

Institutional authors dominate nevertheless the list of most cited references identified by our assessment, as would be expected from their extensively distributed publications. Examples include WCED, the World Bank, the European Commission, the UK Department of the Environment, Transport and Regions [DETR], IPCC, the United Nations, and the Organization for Economic Co-operation and Development [OECD]).

The list of the most cited journals is dominated by Ecological Economics, a specialist journal in the field of sustainable development, followed by Science, Nature and World Development, which are more generalist (Table 6). Some of the highly cited journals have also published influential papers. Ecological Economics, Science, World Development, American Law and Economic Review, and the Proceedings of the National Academy of Sciences of the USA, all have at least $20 \%$ of their citations (comprised in the cited references database used in this paper) in the list of the 380 most influential publications.

Sustainable development principles

Previous research by the authors focused on the identification of the main underlying principles that structure the concept of sustainable development (Quental et al. 2011a). 
Table 5 The ten most cited institutional authors and the 15 most cited individual primary authors

\begin{tabular}{llll}
\hline Author & Background & $\begin{array}{l}\text { Number of } \\
\text { citations }\end{array}$ & $\begin{array}{l}\text { Citations in } \\
\text { the 380 list } \mathrm{a}^{\mathrm{a}} \\
(\%)\end{array}$ \\
\hline
\end{tabular}

Institutional authors

WCED

World Bank

European Commission

DETR (UK)

IPCC

United Nations

OECD

Food and Agriculture

Organization

IUCN

World Health Organization

Individual primary authors

Pearce, D.

Daly, $\mathbf{H}$.

Costanza, R.

Meadows, D.

Redclift, $M$.

Holling, C.

Fearnside, P.

Ayres, R.

Brown, L.

Rees, W.

Solow, R.

Wackernagel, $M$.

Berkes, $\mathbf{F}$.

O'Riordan, T.

Norgaard, $R$.

$\begin{array}{rrr}\mathbf{7 4 4} & \mathbf{1 0 0} & \mathbf{1} \\ 616 & 29 & 194 \\ 387 & 7 & 175 \\ 371 & 6 & 179 \\ \mathbf{3 5 8} & \mathbf{8 4} & \mathbf{2 7} \\ 325 & 6 & 140 \\ 307 & 0 & 155 \\ 282 & 0 & 141 \\ & & \\ \mathbf{1 7 1} & \mathbf{7 3} & \mathbf{2 5} \\ 158 & 0 & 81\end{array}$

$\begin{array}{llll}\text { Economy } & 493 & 57 & 93\end{array}$

Economy

416

67

93

Economy

298

65

55

Environmental

205

87

33

sciences

Sociology

Ecology

199

54

35

196

52

28

Ecology

179

14

44

Economy

167

33

38

Environmentalism

158

10

45

Ecology

153

44

38

Economy

150

62

28

Environmentalism

147

51

31

Ecology

142

47

38

Political sciences

140

18

38

Economy

\section{1}

\section{(17)}

79

40

27

155

41

1

93

a Each author might have one or more references, and each reference has a certain number of citations. This figure is the proportion of citations made to references of that author included in the list of the 380 most cited publications. Authors with more than $30 \%$ of their citations in this list appear bold

These principles could be traced back to different scientific approaches that, the authors argued, eventually led to the modern understanding of the concept. Four main sustainability principles were identified:

- the limits principle: the human economy is embedded within the ecosphere and, as such, sustainability depends on ensuring that the scale of the human economy is low enough to allow the maintenance of healthy life support systems;

- the means and ends principle: natural resources and economy have an instrumental value in fulfilling the ultimate ends of society. Economic growth should not be 
Table 6 The 20 most cited journals a Proportion of citations made to references of a journal included in the list of the 380 most cited publications. Journals with more than $20 \%$ of their citations in this list appear bold

\begin{tabular}{lrr}
\hline Journal & Citations & $\begin{array}{l}\text { Citations in the } \\
380 \text { list }^{\mathrm{a}}(\%)\end{array}$ \\
\hline Ecological Economics & $\mathbf{1 , 4 0 2}$ & $\mathbf{2 3}$ \\
Science & $\mathbf{1 , 3 1 6}$ & $\mathbf{2 2}$ \\
Nature & 696 & 15 \\
World Development & $\mathbf{5 9 1}$ & $\mathbf{2 2}$ \\
Conservation Biology & 524 & 16 \\
Ambio & 449 & 0 \\
Energy Policy & 430 & 0 \\
Environmental Conservation & 384 & 18 \\
Bioscience & 362 & 11 \\
Environmental management & 334 & 12 \\
Global Environmental Change & 324 & 12 \\
American Law and Economics Review & $\mathbf{3 0 6}$ & $\mathbf{3 4}$ \\
Agriculture, Ecosystems \& Environment & 273 & 0 \\
Proceedings of the National Academy & $\mathbf{2 7 2}$ & $\mathbf{2 1}$ \\
$\quad$ of Sciences of the USA & & \\
Climatic Change & 261 & 8 \\
Ecological Applications & 260 & 5 \\
Environment and Planning A & 258 & 4 \\
Environment & 241 & 0 \\
Futures & 221 & 19 \\
Journal of Environmental Economics & 219 & 8 \\
and Management & & \\
\hline
\end{tabular}

understood as an end in itself but as an instrument that can help achieving higher-order ends such as human well-being and freedom;

- the needs principle: each system, and every human being, has its own minimum needs in order to be viable. These irreducible needs must be satisfied independently and cannot be aggregated;

- the complexity principle: systems exhibit complex behavior, namely through multiple stable equilibria and non-linear behavior, and may even collapse when thresholds are reached.

As these principles were derived from a literature review where the subjective judgment of the authors played a role, our aim is to further check whether such principles are also reflected in the major influences of the sustainable development literature as captured by the present bibliometric assessment. Therefore, each of the 60 most influential publications (cf. Appendix Table 7) was screened and assigned either to one sustainability principle or to a sustainability approach (ecological economics, sustainability transition, or sustainability science — cf. Quental et al. 2011a for further details). The result is visually presented in Fig. 3 and shows that all sustainability principles and approaches are well represented in the list of the most influential publications, thus corroborating the accurateness of the review presented in Quental et al. (2011a). Another interesting conclusion is that some publications did not fit that structure of principles and approaches. For example, some influential publications represent results from major sustainable development conferences 
(such as the United Nations Conference on Environment and Development, also known as Rio Summit) or conservation strategies ("The world conservation strategy" and "Caring for the Earth: a strategy for sustainable living"). As they have a strong political character, they were classified as "politics" in Fig. 3. The remainder publications were classified as "others" and include major reports by IPCC, Dryzek's "Environmental discourses: the politics of the Earth", Breheny's "Sustainable development and urban form", and papers reflecting on sustainable development per se.

\section{Discussion and conclusions}

The bibliographic assessment presented in this paper resulted in a wealth of information that requires interpretation. This chapter discusses the range of influences underlying the concept of sustainable development as well as the patterns that characterize the way influence is exerted.

Influences underlying the concept of sustainable development

The Brundtland Commission's report "Our common future" (1987) stands out as the most influential publication found in the sustainable development literature. Classical titles such as Meadows' et al. "Limits to growth" (1972) a Pearce's et al. "Blueprint for a green economy" (1989) follow thereafter. From a thematic perspective, the analysis of the 60 most influential publications is also instructive and reveals a considerable variety of topics:

- reports and reviews about sustainable development or closely related (again, "Our common future" and "Limits to growth", but also the "Millennium Ecosystem Assessment", the IPCC reports, or Lele's "Sustainable development: a critical review");

- policy documents (e.g., "The World Conservation Strategy", the Rio Declaration and Agenda 21);

- environmental, ecological and development economics (Hartwick's "Intergenerational equity", Schumacher's "Small is beautiful", Pearce's et al. "Blueprint for a green economy", Costanza and Daly's "Natural capital and sustainable development", Adams' "Green development", Norgaard's "Development betrayed", etc.);

- valuation of ecosystem services (e.g., Daily's "Nature's services: societal dependence on natural ecosystems", Costanza's et al. "The value of the world's ecosystem services and natural capital");

- ecosystem resilience (e.g., Berkes' et al. "Navigating social-ecological systems", Holling's "Resilience of terrestrial ecosystems" or Walker's et al. "Resilience, adaptability and transformability in social-ecological systems");

- environmental impacts (e.g., Wackernagel's et al. "Tracking the ecological overshoot of the human economy", Vitousek's et al. "Human appropriation of the products of photosynthesis", Von Weizsäcker's et al. "Factor four");

- urban sustainability (Breheny's "Sustainable development and urban form");

- governance of natural resources (Hardin's "Tragedy of the commons", Ostrom's "Governing the commons");

- development and sociology of science (Lubchenco's "Entering the century of the environment: a new social contract for science" or Kates' et al. "Sustainability science"); and 
- political science (Hajer's "Politics of environmental discourse" or Dryzek's "Environmental discourses").

Interestingly enough, as already pointed out in Quental et al. (2011b), the weak outcomes of the Johannesburg Summit in 2002 did not translate into any highly cited publication, contrarily to what happened with the previous Earth Summits.

By aggregating the themes into scientific disciplines one observes an overrepresentation of contributions from the economical (particularly ecological economics) and environmental sciences in the list of the most influential publications, authors and journals. The prominence of economical contributions is in contrast to the mere $11 \%$ of the source literature papers classified as such (cf. Table 3). With an economical background, authors as David Peace, Herman Daly, or Robert Costanza stand out, as well as the journals Ecological Economics, American Law and Economics Review, and the Journal of Environmental Economics and Management. Highly cited authors with a background on environmental sciences include Crawford Holling, Philip Fearnside, William Rees, Fikret Berkes, and journals include Nature, Conservation Biology, Ambio, Environmental Conservation. A smaller but still significant contribution comes from sociology, political sciences, and planning (authors: Michael Redclift, Timothy O'Riordan; journals: World Development, Environment and Planning A, Futures). The diversity of influences is nonetheless indisputable and several publications are truly multidisciplinary. For example, publications addressing social-ecological resilience usually cover both governance issues and ecosystem management, thus reinforcing the idea that sustainability science is, to a large extent, about bridging the gap between different fields of knowledge in what Wilson (1998) called "consilience".

Moving up in the level of abstraction and interpreting the results obtained in "Sustainable development principles", it was shown that the four sustainability principles identified by Quental et al. (2011a) are well represented in the list of the most influential publications, although some publications did not fit into the structure. This is not suggestive, however, of any unaccounted sustainability principle because unaligned publications relate not directly to such principles but to specific dimensions of the sustainability debate (among them, the political dimension should be highlighted).

Patterns and cycles of influence

Only a very restricted group of publications seems to become highly influential. Recall that $87 \%$ of the references has been cited only once by the source literature. This suggests that either such publications were of limited relevance, or that their influence was exerted through other channels where sources are not credited in a formal way (papers may become influential outside the scientific realm studied here). One must also acknowledge that writing a scientific paper is also a process of individual or group knowledge creation and sharing whose main beneficiaries might be the authors themselves. For example, certain scientists might need to publish several less cited papers until a "critical stadium" is achieved and one paper becomes more influential. This idea is reinforced by visual interpretation of Fig. 3 suggests a pattern of landmark studies that frame, about every 5 years, the core of sustainable development influences. Examples include the Hardin's "Tragedy of the commons" (1968), Meadows' et al. "Limits to growth" (1972), the World Conservation Strategy (1980), Brundtland Commission's “Our common future” (1987), the Rio Declaration (1992), the IPCC reports $(1995,2001)$ and the Millennium Ecosystem Assessment (2005). Overall, one can argue that the knowledge contained in a large number 
of less cited references slowly builds up and is somehow consolidated into a limited number of very influential publications. It is therefore advisable to avoid precipitate conclusions about the relevance of less cited papers as they may serve multiple purposes not immediately obvious.

The cycling nature of influence can also be spotted from the analysis of citation trends (cf. Fig. 4). Results suggests that, among the list of the most influential publications, there is a first stage characterized by high citation rates which is then followed by a second stage of declining citation rates and variable long-term citation outcomes. While very influential publications are able to keep relatively high or average citation counts per year, other publications may be more ephemeral.

Author's influence can also assume different patterns. The most influential individuals come from the United States and United Kingdom. Institutional authors, however, dominate the list of the most cited references because they are typically responsible for reports with a global dimension and large dissemination networks. Some authors are very influential because at least one of their publications is highly cited; the influence of others arises from a modest number of citations multiplied by several publications. The latter pattern is typical of very prolific authors whose individual publications obtain, each, only a modest number of citations. An extreme situation happend with OECD: with 307 citations, none of its 155 publications reached the symbolic mark of ten cites (cf. Table 5). Authors such as WCED, IPCC, David Pearce, Herman Daly, Robert Costanza and Donella Meadows could be placed in the former pattern of influence because at least some of their publications are highly cited.

This study has shown that bibliometric assessments can be a useful tool in improving the knowledge about sources influencing specific fields of study. Our results have complemented previous research based on literature reviews (Quental et al. 2011a, b) and identified several highly cited publications that we have not previously taken into consideration. This paper also incorporates selected citation trends and identifies typical patterns of influence by authors and publications, thereby providing an accurate picture of the richness of the sustainable development literature.

Acknowledgments This paper was written as part of a PhD research. The authors would like to credit the financial support provided by Fundação para a Ciência e Tecnologia (the Portuguese research foundation) under scholarship SFRH/BD/18588/2004 and project PTDC/ECM/73069/2006.

\section{Appendix}

See Table 7.

Table 7 The 60 most relevant publications cited in papers containing "sustainable development" or "sustainability science" in their title, abstract or keywords

\begin{tabular}{|c|c|c|c|c|c|}
\hline Year & Authors & Title & Journal $^{\mathrm{a}}$ & Citations & Rank $^{b}$ \\
\hline 1987 & WCED & Our common future & (Book) & 744 & $\begin{array}{l}\text { (1) } \\
22.5 \%\end{array}$ \\
\hline 2001 & IPCC & $\begin{array}{l}\text { IPCC: 3rd assessment (all } \\
\text { reports) }\end{array}$ & (Book) & 158 & $\begin{array}{l}(2) \\
9.7 \%\end{array}$ \\
\hline 2005 & MEA & $\begin{array}{l}\text { Ecosystems and human well- } \\
\text { being (all reports) }\end{array}$ & (Book) & 45 & $\begin{array}{l}(3) \\
5.9 \%\end{array}$ \\
\hline 1989 & Pearce, D. et al. & Blueprint for a green economy & (Book) & 140 & $\begin{array}{l}\text { (4) } \\
4.3 \%\end{array}$ \\
\hline
\end{tabular}


Table 7 continued

\begin{tabular}{|c|c|c|c|c|c|}
\hline Year & Authors & Title & Journal $^{\mathrm{a}}$ & Citations & Rank $^{b}$ \\
\hline 1972 & $\begin{array}{l}\text { Meadows, D. } \\
\text { et al. }\end{array}$ & The limits to growth & (Book) & 124 & $\begin{array}{l}\text { (5) } \\
3.7 \%\end{array}$ \\
\hline 2001 & Kates, R. et al. & Sustainability science & Science & 56 & $\begin{array}{l}\text { (6) } \\
3.5 \%\end{array}$ \\
\hline 1989 & $\begin{array}{l}\text { Daly, H. and } \\
\text { Cobb, J. }\end{array}$ & For the common good & (Book) & 113 & $\begin{array}{l}\text { (7) } \\
3.4 \%\end{array}$ \\
\hline 1995 & IPCC & $\begin{array}{l}\text { IPCC: } 2 \text { nd assessment (all } \\
\text { reports) }\end{array}$ & (Book) & 95 & $\begin{array}{l}(8) \\
3.4 \%\end{array}$ \\
\hline 2003 & Turner, B. et al. & $\begin{array}{l}\text { A framework for vulnerability } \\
\text { analysis in sustainability } \\
\text { science }\end{array}$ & PNAS & 34 & $\begin{array}{l}(9) \\
3.2 \%\end{array}$ \\
\hline 1997 & $\begin{array}{l}\text { Costanza, } \mathbf{R} . \\
\text { et al. }\end{array}$ & $\begin{array}{l}\text { The value of the world's } \\
\text { ecosystem and natural capital }\end{array}$ & Nature & 65 & $\begin{array}{l}\text { (10) } \\
2.6 \%\end{array}$ \\
\hline 1992 & United Nations & $\begin{array}{l}\text { United Nations Conference on } \\
\text { Environment and } \\
\text { Development_-Agenda } 21\end{array}$ & (Document) & 81 & $\begin{array}{l}(11) \\
2.6 \%\end{array}$ \\
\hline 1980 & IUCN et al. & The world conservation strategy & (Book) & 83 & $\begin{array}{l}(12) \\
2.5 \%\end{array}$ \\
\hline 1968 & Hardin, G. & The tragedy of the commons & Science & 79 & $\begin{array}{l}\text { (13) } \\
2.4 \%\end{array}$ \\
\hline 1987 & Redclift, M. & $\begin{array}{l}\text { Sustainable development: } \\
\text { exploring the contradictions }\end{array}$ & (Book) & 74 & $\begin{array}{l}(14) \\
2.2 \%\end{array}$ \\
\hline 1991 & Lele, S. & $\begin{array}{l}\text { Sustainable development: a } \\
\text { critical review }\end{array}$ & $\begin{array}{l}\text { World } \\
\text { Development }\end{array}$ & 67 & $\begin{array}{l}(15) \\
2.1 \%\end{array}$ \\
\hline 1973 & Daly, $\mathrm{H}$. & Toward a steady-state economy & (Book) & 65 & $\begin{array}{l}(16) \\
2.0 \%\end{array}$ \\
\hline 1990 & Ostrom, E. & $\begin{array}{l}\text { Governing the commons: the } \\
\text { evolution of institutions for } \\
\text { collective action }\end{array}$ & (Book) & 60 & $\begin{array}{l}\text { (17) } \\
1.8 \%\end{array}$ \\
\hline 1996 & $\begin{array}{l}\text { Wackernagel, M. } \\
\text { and Rees, W. }\end{array}$ & $\begin{array}{l}\text { Our ecological footprint: } \\
\text { reducing human impact on } \\
\text { the Earth }\end{array}$ & (Book) & 49 & $\begin{array}{l}\text { (18) } \\
1.8 \%\end{array}$ \\
\hline 1999 & Kaygusuz, K. & $\begin{array}{l}\text { The viability of thermal energy } \\
\text { storage }\end{array}$ & Energy Sources & 37 & $\begin{array}{l}(19) \\
1.7 \%\end{array}$ \\
\hline 1992 & $\begin{array}{l}\text { Meadows, D. } \\
\text { et al. }\end{array}$ & Beyond the limits & (Book) & $\mathbf{5 5}$ & $\begin{array}{l}(20) \\
1.7 \%\end{array}$ \\
\hline 2003 & Berkes, F. et al. & $\begin{array}{l}\text { Navigating social-ecological } \\
\text { systems: building resilience for } \\
\text { complexity and change }\end{array}$ & (Book) & 17 & $\begin{array}{l}(21) \\
1.6 \%\end{array}$ \\
\hline 1999 & $\begin{array}{l}\text { National } \\
\text { Academy of } \\
\text { Sciences }\end{array}$ & $\begin{array}{l}\text { Our common journey: a } \\
\text { transition toward sustainability }\end{array}$ & (Book) & 33 & $\begin{array}{l}(22) \\
1.6 \%\end{array}$ \\
\hline 1997 & Daily, G. (Ed.) & $\begin{array}{l}\text { Nature's services: societal } \\
\text { dependence on natural } \\
\text { ecosystems }\end{array}$ & (Book) & 39 & $\begin{array}{l}\text { (23) } \\
1.6 \%\end{array}$ \\
\hline 1995 & Hajer, M. & $\begin{array}{l}\text { The politics of environmental } \\
\text { discourse: ecological } \\
\text { modernization and the policy } \\
\text { process }\end{array}$ & (Book) & 40 & $\begin{array}{l}(24) \\
1.4 \%\end{array}$ \\
\hline
\end{tabular}


Table 7 continued

\begin{tabular}{|c|c|c|c|c|c|}
\hline Year & Authors & Title & Journal $^{\mathrm{a}}$ & Citations & Rank $^{\mathrm{b}}$ \\
\hline 1990 & $\begin{array}{l}\text { Pearce, D. and } \\
\text { Turner, R. }\end{array}$ & $\begin{array}{l}\text { Economics of natural resources } \\
\text { and the environment }\end{array}$ & (Book) & 46 & $\begin{array}{l}(25) \\
1.4 \%\end{array}$ \\
\hline 1977 & Hartwick, J. & $\begin{array}{l}\text { Intergenerational equity and } \\
\text { the investing of rents from } \\
\text { exhaustible resources }\end{array}$ & $\begin{array}{l}\text { American } \\
\text { Economic } \\
\text { Review }\end{array}$ & 46 & $\begin{array}{l}\text { (26) } \\
1.4 \%\end{array}$ \\
\hline 2002 & $\begin{array}{l}\text { Gunderson, L. and } \\
\text { Holling, C. }\end{array}$ & $\begin{array}{l}\text { Panarchy: understanding } \\
\text { transformations in human and } \\
\text { natural systems }\end{array}$ & (Book) & 18 & $\begin{array}{l}(27) \\
1.3 \%\end{array}$ \\
\hline 2004 & Walker, B. et al. & $\begin{array}{l}\text { Resilience, adaptability and } \\
\text { transformability in social- } \\
\text { ecological systems }\end{array}$ & $\begin{array}{l}\text { Ecology and } \\
\text { Society }\end{array}$ & 10 & $\begin{array}{l}(28) \\
1.3 \%\end{array}$ \\
\hline 1993 & $\begin{array}{l}\text { Pearce, D. and } \\
\text { Atkinson, G. }\end{array}$ & $\begin{array}{l}\text { Capital theory and the } \\
\text { measurement of sustainable } \\
\text { development: an indicator } \\
\text { of" weak" sustainability }\end{array}$ & $\begin{array}{l}\text { Ecological } \\
\text { Economics }\end{array}$ & 40 & $\begin{array}{l}\text { (29) } \\
1.3 \%\end{array}$ \\
\hline 1991 & IUCN et al. & $\begin{array}{l}\text { Caring for the Earth: a strategy } \\
\text { for sustainable living }\end{array}$ & (Book) & 41 & $\begin{array}{l}(30) \\
1.3 \%\end{array}$ \\
\hline 1991 & $\begin{array}{l}\text { Costanza, R. } \\
\text { (Ed.) }\end{array}$ & $\begin{array}{l}\text { Ecological economics: the } \\
\text { science and management of } \\
\text { sustainability }\end{array}$ & (Book) & 40 & $\begin{array}{l}\text { (31) } \\
1.2 \%\end{array}$ \\
\hline 1986 & Holling, C. & $\begin{array}{l}\text { The resilience of terrestrial } \\
\text { ecosystems: local surprise and } \\
\text { global change (in sustainable } \\
\text { development of the biosphere) }\end{array}$ & (Book chapter) & 41 & $\begin{array}{l}(32) \\
1.2 \%\end{array}$ \\
\hline 2003 & Cash, D. et al. & $\begin{array}{l}\text { Knowledge systems for } \\
\text { sustainable development }\end{array}$ & PNAS & 13 & $\begin{array}{l}(33) \\
1.2 \%\end{array}$ \\
\hline 1999 & Hawken, P. et al. & $\begin{array}{l}\text { Natural capitalism: creating the } \\
\text { next industrial revolution }\end{array}$ & (Book) & 25 & $\begin{array}{l}(34) \\
1.2 \%\end{array}$ \\
\hline 1997 & Dryzek, J. & $\begin{array}{l}\text { Environmental discourses: the } \\
\text { politics of the Earth }\end{array}$ & (Book) & 29 & $\begin{array}{l}(35) \\
1.2 \%\end{array}$ \\
\hline 1997 & Vitousek, P. et al. & $\begin{array}{l}\text { Human domination of Earth's } \\
\text { ecosystems }\end{array}$ & Science & 29 & $\begin{array}{l}\text { (36) } \\
1.2 \%\end{array}$ \\
\hline 1987 & Barbier, E. & $\begin{array}{l}\text { The concept of sustainable } \\
\text { economic development }\end{array}$ & $\begin{array}{r}\text { Environmental } \\
\text { Conservation }\end{array}$ & 37 & $\begin{array}{l}(37) \\
1.1 \%\end{array}$ \\
\hline 1992 & $\begin{array}{l}\text { Costanza, R. and } \\
\text { Daly, H. }\end{array}$ & $\begin{array}{l}\text { Natural capital and sustainable } \\
\text { development }\end{array}$ & $\begin{array}{l}\text { Conservation } \\
\text { Biology }\end{array}$ & 35 & $\begin{array}{l}\text { (38) } \\
1.1 \%\end{array}$ \\
\hline 1987 & $\begin{array}{l}\text { Blaikie, P. and } \\
\text { Brookfield, H. }\end{array}$ & Land degradation and society & (Book) & 36 & $\begin{array}{l}(39) \\
1.1 \%\end{array}$ \\
\hline 1971 & $\begin{array}{l}\text { Georgescu- } \\
\text { Roegen, } \mathbf{N} .\end{array}$ & $\begin{array}{l}\text { The entropy law and the } \\
\text { economic progress }\end{array}$ & (Book) & 36 & $\begin{array}{l}\text { (40) } \\
1.1 \%\end{array}$ \\
\hline 1990 & Adams, W. & $\begin{array}{l}\text { Green development: environment } \\
\text { and development in the third } \\
\text { world }\end{array}$ & (Book) & 35 & $\begin{array}{l}(41) \\
1.1 \%\end{array}$ \\
\hline 1991 & Jacobs, M. & The green economy & (Book) & 34 & $\begin{array}{l}(42) \\
1.1 \%\end{array}$ \\
\hline 1992 & United Nations & $\begin{array}{l}\text { United Nations Conference on } \\
\text { Environment and } \\
\text { Development-Rio Declaration }\end{array}$ & (Document) & 33 & $\begin{array}{l}(43) \\
1.0 \%\end{array}$ \\
\hline
\end{tabular}


Table 7 continued

\begin{tabular}{|c|c|c|c|c|c|}
\hline Year & Authors & Title & Journal $^{\mathrm{a}}$ & Citations & Rank $^{\mathrm{b}}$ \\
\hline 1993 & Ludwig, D. et al. & $\begin{array}{l}\text { Uncertainty, resource } \\
\text { exploitation, and } \\
\text { conservation: lessons from } \\
\text { history }\end{array}$ & Science & 32 & $\begin{array}{l}\text { (44) } \\
1.0 \%\end{array}$ \\
\hline 1995 & $\begin{array}{l}\text { Porter, M. and van } \\
\text { der Linde, C. }\end{array}$ & $\begin{array}{l}\text { Green and competitive-ending } \\
\text { the stalemate }\end{array}$ & $\begin{array}{l}\text { Harvard Business } \\
\text { Review }\end{array}$ & 29 & $\begin{array}{l}(45) \\
1.0 \%\end{array}$ \\
\hline 1990 & IPCC & IPCC: 1 st assessment (all reports) & & 33 & $\begin{array}{l}(46) \\
1.0 \%\end{array}$ \\
\hline 1997 & $\begin{array}{l}\text { Von Weizsäcker, } \\
\text { E. et al. }\end{array}$ & $\begin{array}{l}\text { Factor four: doubling wealth, } \\
\text { halving resource use }\end{array}$ & (Book) & 25 & $\begin{array}{l}(47) \\
1.0 \%\end{array}$ \\
\hline 1992 & Beck, U. & $\begin{array}{l}\text { Risk society: towards a new } \\
\text { modernity }\end{array}$ & (Book) & 31 & $\begin{array}{l}(48) \\
1.0 \%\end{array}$ \\
\hline 1994 & Norgaard, $\mathbf{R}$. & $\begin{array}{l}\text { Development betrayed: the end } \\
\text { of progress and a } \\
\text { coevolutionary revisioning of } \\
\text { the future }\end{array}$ & (Book) & 29 & $\begin{array}{l}\text { (49) } \\
1.0 \%\end{array}$ \\
\hline 1973 & Holling, C. & $\begin{array}{l}\text { Resilience and stability of } \\
\text { ecological systems }\end{array}$ & $\begin{array}{l}\text { Annual Reviews of } \\
\text { Ecology and } \\
\text { Systematics }\end{array}$ & 32 & $\begin{array}{l}\text { (50) } \\
1.0 \%\end{array}$ \\
\hline 1998 & Lubchenco, J. & $\begin{array}{l}\text { Entering the century of the } \\
\text { environment: a new social } \\
\text { contract for science }\end{array}$ & Science & 21 & $\begin{array}{l}(51) \\
0.9 \%\end{array}$ \\
\hline 1986 & Vitousek, P. et al. & $\begin{array}{l}\text { Human appropriation of the } \\
\text { products of photosynthesis }\end{array}$ & Bioscience & 30 & $\begin{array}{l}(52) \\
0.9 \%\end{array}$ \\
\hline 2002 & Eissen, M. et al. & $\begin{array}{l}10 \text { years after rio-concepts on the } \\
\text { contribution of chemistry to a } \\
\text { sustainable development }\end{array}$ & $\begin{array}{l}\text { Angewandte } \\
\text { Chemie }\end{array}$ & 12 & $\begin{array}{l}(53) \\
0.9 \%\end{array}$ \\
\hline 2002 & Raskin, P. et al. & $\begin{array}{l}\text { Great transition: the promise and } \\
\text { lure of the times ahead }\end{array}$ & (Book) & 12 & $\begin{array}{l}(54) \\
0.9 \%\end{array}$ \\
\hline 2002 & $\begin{array}{l}\text { Wackernagel, M. } \\
\text { et al. }\end{array}$ & $\begin{array}{l}\text { Tracking the ecological } \\
\text { overshoot of the human } \\
\text { economy }\end{array}$ & PNAS & 12 & $\begin{array}{l}(55) \\
\quad 0.9 \%\end{array}$ \\
\hline 1973 & Schumacher, E. & $\begin{array}{l}\text { Small is beautiful: a study of } \\
\text { economics as if people } \\
\text { mattered }\end{array}$ & (Book) & 29 & $\begin{array}{l}(56) \\
0.9 \%\end{array}$ \\
\hline 1998 & $\begin{array}{l}\text { Berkes, F. and } \\
\text { Folke, C. (Eds.) }\end{array}$ & $\begin{array}{l}\text { Linking social and ecological } \\
\text { systems }\end{array}$ & (Book) & 20 & $\begin{array}{l}(57) \\
0.9 \%\end{array}$ \\
\hline 2001 & Scheffer, M. et al. & $\begin{array}{l}\text { Catastrophic regime shifts in } \\
\text { ecosystems }\end{array}$ & (Book) & 14 & $\begin{array}{l}(58) \\
0.9 \%\end{array}$ \\
\hline 1992 & Breheny, M. (Ed.) & $\begin{array}{l}\text { Sustainable development and } \\
\text { urban form }\end{array}$ & (Book) & 27 & $\begin{array}{l}(59) \\
0.9 \%\end{array}$ \\
\hline 1979 & $\begin{array}{l}\text { Dasgupta, P. and } \\
\text { Heal, G. }\end{array}$ & $\begin{array}{l}\text { Economic theory and exhaustible } \\
\text { resources }\end{array}$ & (Book) & 28 & $\begin{array}{l}(60) \\
0.8 \%\end{array}$ \\
\hline
\end{tabular}

\footnotetext{
a If applicable

${ }^{b}$ Ranking criterion is the percentage of citing papers published after the publication in question. Only references with 10 or more citations are included

Note: Bolded publications were also identified by Ma and Stern (2006) or by Costanza et al. (2004) as influential
} 


\section{References}

Bornmann, L., \& Daniel, H. D. (2008). What do citation counts measure? A review of studies on citing behavior. Journal of Documentation, 64(1), 45-80.

Clark, W. C., \& Dickson, N. M. (2003). Sustainability science: The emerging research program. Proceedings of the National Academy of Sciences of the United States of America, 100(14), 8059-8061.

Costanza, R., Stern, D., Fisher, B., He, L. N., \& Ma, C. B. (2004). Influential publications in ecological economics: A citation analysis. Ecological Economics, 50(3-4), 261-292.

Garfield, E. (1972). Citation analysis as a tool in journal evaluation. Science, 178(60), 471-479.

Glänzel, W., \& Moed, H. F. (2002). Journal impact measures in bibliometric research. Scientometrics, 53(2), $171-193$.

ISI. (2008). Web of Science [Online]. Retrieved March 21, 2008 from http://apps.isiknowledge.com.

Kajikawa, Y., Ohno, J., Takeda, Y., Matsushima, K., \& Komiyama, H. (2007). Creating an academic landscape of sustainability science: An analysis of the citation network. Sustainability Science, 2(2), 221-231.

Kates, R., Clark, W. C., Robert Corell, J., Hall, M., Jaeger, C. C., Lowe, I., et al. (2001). Sustainability science. Science, 292(5517), 641-642.

Ma, C. B., \& Stern, D. I. (2006). Environmental and ecological economics: A citation analysis. Ecological Economics, 58, 491-506.

MacRoberts, M. H., \& MacRoberts, B. R. (1996). Problems of citation analysis. Scientometrics, 36(3), 435-444.

Quental, N., Lourenço, J. M., \& Nunes da Silva, F. (2011a). Sustainability: Characteristics and scientific roots. Environment Development and Sustainability, 13(2), 257-276.

Quental, N., Lourenço, J. M., \& Nunes da Silva, F. (2011b). Sustainable development policy: Goals, targets and political cycles. Sustainable Development, 19(1), 15-29.

Schubert, A., \& Lang, I. (2005). The literature aftermath of the Brundtland report 'Our Common Future'. A Scientometric study based on citations in science and social science journals. Environment, Development and Sustainability, 7(1), 1-8.

United Nations Center for Human Settlements. (2008). State of the world's cities: 2008/2009: Harmonious cities. London: Earthscan.

United Nations Population Fund. (2007). Situação da população mundial 2007: desencadeando o potencial do crescimento urbano. New York: United Nations Population Fund.

Vieira, E., \& Gomes, J. (2010). Citations to scientific articles: Its distribution and dependence on the article features. Journal of Informetrics, 4(1), 1-13.

WCED. (1987). Our common future. : Oxford University Press.

Wikipedia (2011). Fields of science [Online]. Retrieved from http://en.wikipedia.org/wiki/Fields_of_science. Wilson, E. O. (1998). Consilience: The unity of knowledge. New York: Abacus. 